\title{
Making the best of a Human modified Habitat; an Assessment of Avian Distribution and Diversity in Federal College of Education (Technical) Gombe. Gombe State- Nigeria
}

\author{
Nsor, C. $\mathrm{A}^{1}$; Aliyu, $\mathrm{B}^{1}$; Zhigla, $\mathrm{D}^{1}$; Dauda, $\mathrm{E}^{1}$ and Cleophas, B. $\mathrm{A}^{1}$ \\ Department of Biological Sciences, Gombe State University- Gombe Nigeria. \\ Corresponding author:charlesnsor@yahoo.co.uk
}

\begin{abstract}
We assessed the abundance and diversity of avian species in two distinct habitats types; main campus area (human inhabited) and adjoining heavily degraded savannah grassland. By employing Jaccard/Tanimoto Coefficient of Similarity, we tested whether bird species assemblage will differ between the two habitats, while Shannon Weiner Diversity Index was used to determine the level of diversity between sites.
\end{abstract}

Line transect assessment generated a total of 1035 individuals of 69 avian species from 53 genera and 32 families. The most diverse avian family was Estrildidae with nine (9) avian species, followed by Columbidae with six (6), while Falconidae, Nectriniidae, and Turdidae families had a record of four (4) species each. Five families (Ardeidae, Malaconotidae, Ploceidae, Silviidae, Sturnidae) and five families (Accipitridae, Bucerotidae, Capitonidae, Viduidaeand Psittacidae) followed with three (3) and (2) species respectively. Seventeen (17) families were each represented by a single species.

Jaccard/Tanimoto Coefficient revealed that species composition differed between the two habitats with a similarity coefficient of $66.7 \%$, while Shannon Weiner Diversity Index was 1.56 and 1.67 for human inhabited (HI) and degraded savannah (DS) habitats respectively. The proximity to a natural savannah habitat albeit degraded has positive implications for avian diversity in the study area. We recommend more exclusion of human activities such as fuel wood harvesting and land grab for farming as this has grave consequences for the thriving population of species that are sensitive to human presence and urbanization.

Keywords-Avian species, Diversity, Habitat utilization, Disturbance. Abundance.

\section{INTRODUCTION}

One of the most outstanding features of birds is their high mobility and ability to travel great distances even across oceans (Borrow and Demey, 2001). Birds occur in all habitats known to man. (Mann and Cheke, 2001); the ubiquitous nature of birds and their sensitivity to ecosystem change makes them a very important component of biodiversity, and as such; birds are often used as good indicators of the state of health of the environment (Pearce and Ferrier, 2001; Gregory et al., 2003; Krisanti et al., 2017). Birds reflect changes in other biodiversity (example other animals and plants) and are highly responsive to environmental perturbations; making them very useful in studies designed to address the effects of human and other environmental disturbances on community stability and ecosystem productivity (Ezealor, 2002; Gregory et al., 2009). Birds contribute substantially to the overall species richness of West African forests, currently recognized as biodiversity hots pots of global importance (Orme et al., 2005).

Species diversity is a community attribute that is directly related to ecosystem productivity and vegetation structure (Tilman, 1996). Research has shown that species diversity is directly linked with habitat structure(James and Warner, 1982) as well as patterns of distribution of resources within a given ecological setting (Pringle et al., 2010).

The pattern and distribution of species has serious implication for community productivity. For instance, Pringle et al. (2010) proved that the regular (even spacing) spatial pattern of termite mounds found in a homogeneous African savannah provided a guide for parallel spatial patterning in tree-dwelling, termite-eating animal communities. Their findings, which also confirm that the uniformity of these patterns at small spatial scales boosted productivity of the whole landscape; provide support for 
models linking spatial patterns with ecosystem processes and functioning (Memmott et al, 2004; Bakam et al., 2018).

In the same manner, we explored how habitat structure and resource availability in a human modified habitat will affect avian distribution, abundance and diversity (Odewumi et al., 2017). We tested whether species will partition resource use along a gradient of disturbance in the study area (Agbo et al., 2018). This was possible considering the fact that the campus is contiguous to a natural but patchy and degraded savannah landscape made of some remnant native tree species. Our experimental approach was guided by the fact that vegetation structure is the most proximate factor that determines the spatial distribution of species (James and Warner, 1982); and more specifically bird diversity, enhanced by the plant species composition (Manu et al., 2007; Manu et al., 2010). The goal of this study was therefore to determine how well birds utilize human modified habitats as well as the factors that may be crucial for their persistence in this degraded landscape. Specific objectives were to;

i. Develop a comprehensive checklist of the area.

ii. Identify the most abundant species in the study area iii.

Determine whether species composition (diversity) will differ between the two sites.

\section{MATERIALS AND METHODS}

\subsection{Study Area}

The study was conducted in The Federal College of Education (Technical Gombe), established in 1977. The college operated elsewhere for 17 years before moving to the present campus (permanent site)in 1996. The College is located along Ashaka road (Latitude 10 18'.30" $\mathrm{N}$, Longitude $11^{\circ} 9^{\prime} .30^{\prime \prime}$ E.) in Akko Local Government Area, Gombe.

The annual rainfall ranges from 850 to $1000 \mathrm{~mm}$, with two distinct seasons; rainy and dry seasons. The rainy season starts from May to October and dry season from November to April. Average daily temperatures are $34^{\circ} \mathrm{C}$ in April and $27^{\circ} \mathrm{C}$ in August. The relative humid ity ranges from 70 to 80 $\%$ in August and decreases to about 15 to $20 \%$ in December.

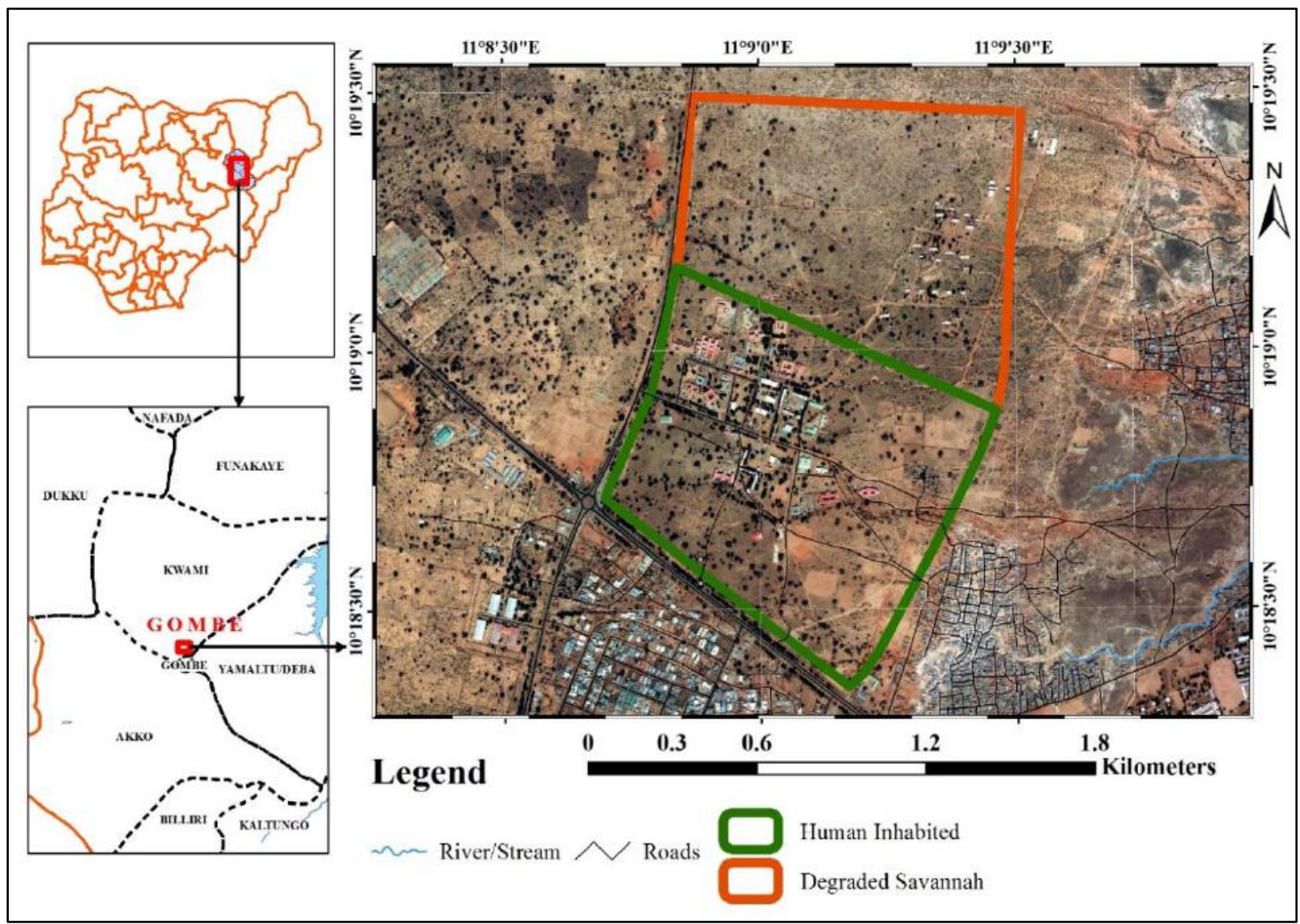

Fig.1: Map of study Area showing the two habitat types (human inhabited and degraded savannah).

The college lies within the Sudano-Sahelian Savannah vegetation typified by shrubs and sparsely distributed tree species. Regrettably, as is typical with most human modified habitats, the campus flora is now dominated by exotic and 
introduced tree species interspersed with a few remnant natives, the most prominent being Parkia biglobosa and Tamarindus indica. The college is divided into two unique habitats; the campus area hereinafter referred to as the human inhabited (HI) contiguous to a degraded savannah (DS) (Fig 1). The most common native tree species in the degraded savannah habitat was Parkia biglobosa while Azadaricta indica (Neem) was the most common tree species in the human occupied habitat.

\subsection{Experimental Design}

Line transect method (Bibly et al, 2000) was used to estimate and record bird species seen or heard within the study area. The campus was divided into two major habitat types; Degraded Savannah (DS) and Human inhabited (HI), with each habitat comprising of three transects. Each transect was located at a horizontal distance of $250 \mathrm{~m}$ apart to ensure that the same bird species was not recorded repeatedly in a given transect. Each transect covered a total distance of 2000 meters.

Transects were monitored twice each day in the morning and later in the evening. The morning session commenced at 6:30 am and lasted till about 9:30 am, while the evening sessions were conducted between the hours of 3:30 pm $-6: 30 \mathrm{pm}$. During each transect survey we walked slowly along each transect and recorded bird species seen at least 50 mon either side of the transect or heard (Bibly et al, 2000). With the help of a pair of (Nikon sporter ${ }^{\circledR} 8 \times 42$ ) binoculars we recorded the number seen and estimated the distance away from the transect. Each transect was repeated twice to optimize the record. The survey was conducted in 2016 during the end of the dry season and towards the onset of the rains .

Data generated from the survey was entered in excel spreadsheet version 2013 and explored before exporting same to SPSS. The statistical Package for Social Science (SPSS version 19.0 was used to analyze the data. Descriptive statistics was used to determine the frequency and numerical abundance of each avian species. Shannon Weiner Diversity index was employed to determine the species diversity and evenness in the study area and for each of the two habitats.

We calculated the level of similarity in species composition between the two habitats based on the Jaccard/Tanimoto Coefficient; which is one of the metrics deployed to compare the similarity and diversity of sample sets. It uses the ratio of the intersecting set to the union set as the measure of similarity or dissimilarity. Thus it equals to zero if there are no intersecting elements and equals to one if all elements intersect (common species to both sets). This was explored using the equation below;

$$
\begin{gathered}
T=\frac{N_{c}}{N_{a}+N_{b}-N_{c}} \quad \text { Equation } 1 \\
N_{a-} \text { number of element in set A } \\
N_{b-} \quad \text { number of elements in set B } \\
N_{c-} \quad \text { number of elements in intersecting set }
\end{gathered}
$$

Shannon Wiener Diversity Index was used to estimate avian diversity of the study area. Effective nu mber of species (Jost, 2006) was used to determine the pattern of distribution (even or uneven) of avian species. The closer the value of Effective number of species to the species richness (actual species count), the more even the distribution of the species and viceversa.

Shannon Wiener Diversity Index was calculated using the formular below:

$\mathrm{H}^{\prime}-\sum_{i=1}^{s} p_{i} \log _{e} p_{i}$

Equation 2

Where $\mathrm{H}^{\prime}=$ Shannon Wiener Index

$\mathrm{Pi}=$ the proportion of individuals of species " $\mathrm{i}$ " in relation to the total population of all species.

$\log _{\mathrm{e}}=$ Natural logarithm of base e. To get the effective number of species, (the true value of diversity), we used the equation

$\exp \left(\mathrm{H}^{\prime}\right)$ or $\exp \left(-\sum_{i=1}^{s} p_{i} \log _{e} p_{i}\right)$

Equation 3

\section{RESULTS}

A total of 1035 individuals of 69 avian species from 53 genera and 32families were recorded at the end of a four day transect survey with two days dedicated to each of the habitat types (Table 2). The most diverse avian family was the Estrildidae family with nine (9) avian species, followed by Colu mbidae with six (6), while Falconidae, Nectriniidae, and Turdidae families had a record of four (4) species each. Five families (Ardeidae, Malaconotidae, Ploceidae, Silviidae, Sturnidae) and five families (Accipitridae, Bucerotidae, Capitonidae, Viduadae and Psittacidae) followed with three (3) and (2) species respectively. However, 17 families were each represented by a single species (Table 1).

Laughing Dove Streptopelia senegalensis was the most abundant bird species with a total of 96 individuals sited in both habitats. Cattle egret Bulbus ibis and Vinaceous dove Streptopelia vinacea followed with 46 and 41 individuals respectively.

Jaccard/ Tanimoto coefficient of similarity revealed that the two habitats differed in species composition with a percentage difference of $33.3 \%$. Jaccard/Tanimoto 
coefficient was 0.6666 implying that the two habitats were $66.7 \%$ similar in avian species composition. A total of 65 of the 69 species were recorded in the degraded savannah habitat (DS), while 50 species were recorded in the Human inhabited habitat (HI). Interestingly 19 and 4 species were unique to degraded savannah and Human occupied habitats respectively. However, 46 species were common to both habitats.
Shannon Weiner Diversity Index for Human occupied habitat was 1.56 with an effective number of diversity (true diversity) of 4.77 . This was almost the same for degraded savannah with 1.67 and 5.32 for SWI and effective number of species respectively.

Investigations to determine the most common feeding guild in the study area revealed that 21 species were frugivorous, while 18 and 16 species were insectivorous and granivorous respectively (Fig. 2).

Table.1: Distribution of avian species across the 32 families recorded in the study area

\begin{tabular}{|l|ll|lc|}
\hline S/n & Families & Number of species & Families & Number of species \\
\hline 1 & Accipitridae & 2 & Malaconidae & 3 \\
2 & Alcedinidae & 1 & Musophagidae & 1 \\
3 & Ardeidae & 3 & Nectriniidae & 4 \\
4 & Bucerotidae & 2 & Oriolidae & 1 \\
5 & Capitonidae & 2 & Paridae & 1 \\
6 & Charadridae & 1 & Passeridae & 1 \\
7 & Ciconiidae & 1 & Phasiantidae & 1 \\
8 & Cisticolidae & 1 & Picidae & 1 \\
9 & Columbidae & 6 & Ploceidae & 3 \\
10 & Coraciidae & 1 & Psittacidae & 2 \\
11 & Corvidae & 1 & Pyconotidae & 1 \\
12 & Cuculidae & 1 & Silviidae & 3 \\
13 & Estrildidae & 9 & Sturnidae & 3 \\
14 & Falconidae & 4 & Turnidae & 4 \\
15 & Hirundiniidae & 1 & Viduadae & 2 \\
16 & Laniidae & 1 & Zosteropidae & 1 \\
\hline
\end{tabular}

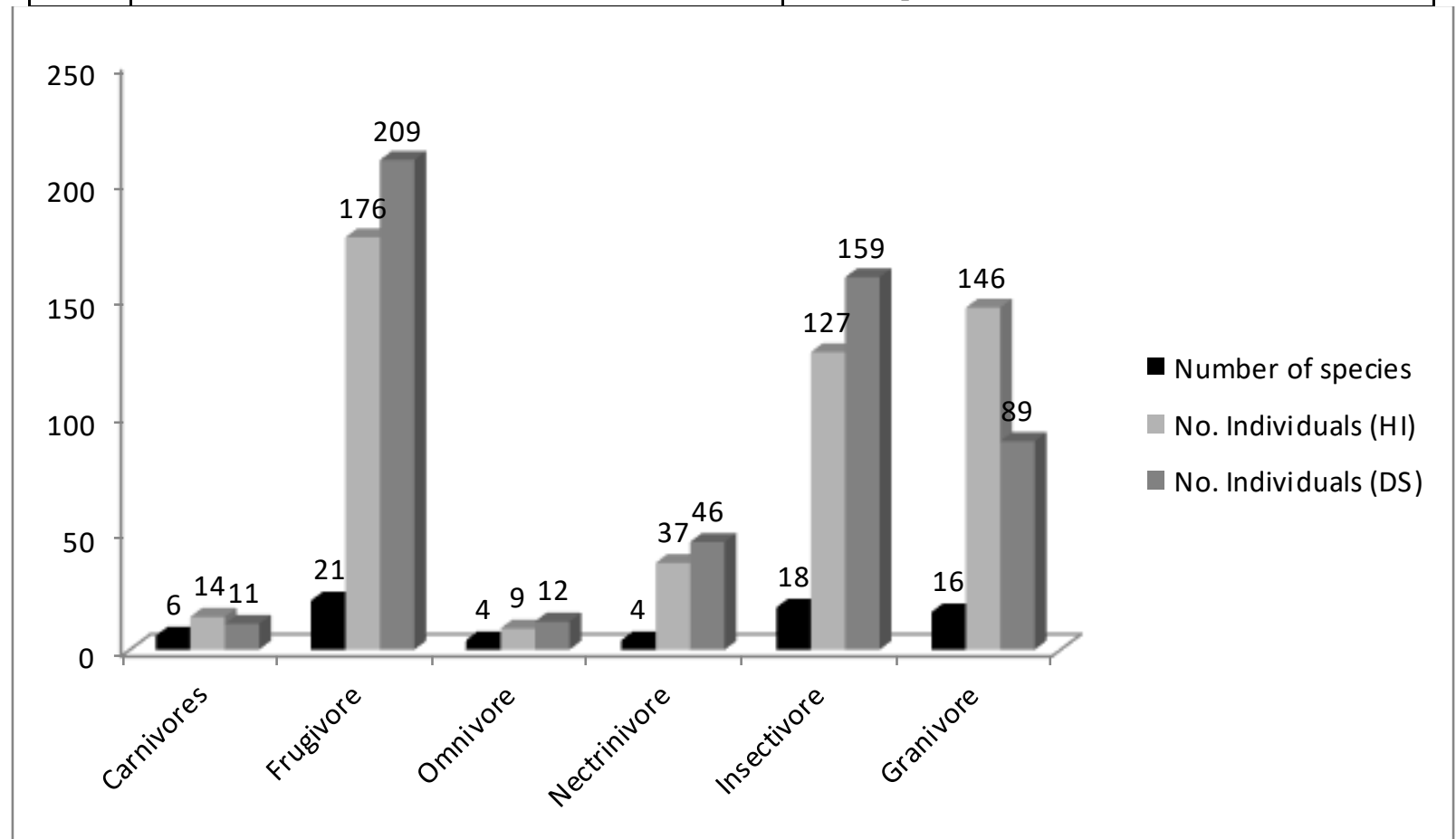

Fig.2: Distribution and abundance of avian species across feeding guilds between the two habitats; HI= Human inhabited, DS = Degraded savannah). 
Table.2: Checklist of avian species of the Federal College of Education (Technical) Gombe, Gombe State. $\sqrt{=}$ present, - = absent

\begin{tabular}{|c|c|c|c|c|c|c|}
\hline $\begin{array}{l}\mathbf{S} / \\
\mathbf{N}\end{array}$ & Species & Scientific name & Family & $\begin{array}{l}\text { Human } \\
\text { Inhabited }\end{array}$ & $\begin{array}{l}\text { Degraded } \\
\text { Savannah }\end{array}$ & $\begin{array}{l}\text { Feeding } \\
\text { Guild }\end{array}$ \\
\hline 1 & Cattle Egret & Bulbusibis & Ardeidae & $\sqrt{ }$ & $\sqrt{ }$ & Insectivore \\
\hline 2 & Black headed heron & Ardeame lanocephala & Ardeidae & - & $\sqrt{ }$ & Insectivore \\
\hline 3 & Grey heron & Ardea cinerea & Ardeidae & - & $\sqrt{ }$ & Insectivore \\
\hline 4 & Abdim stork & Ciconia abdimii & Ciconiidae & $\sqrt{ }$ & $\sqrt{ }$ & Insectivore \\
\hline 5 & Black headed lapwing & Vanellus tetus & Charadridae & $\sqrt{ }$ & $\sqrt{ }$ & Insectivore \\
\hline 6 & Black shouldered kite & Elanus caeruleus & Accipitridae & $\sqrt{ }$ & $\sqrt{ }$ & Carnivore \\
\hline 7 & Shikira & Accipiter badius & Accipitridae & $\sqrt{ }$ & $\sqrt{ }$ & Carnivore \\
\hline 8 & Grey Kestrel & Falco ardosiaceus & Falconidae & $\sqrt{ }$ & $\sqrt{ }$ & Carnivore \\
\hline 9 & Lanner falcon & Falco biarmicus & Falconidae & $\sqrt{ }$ & $\sqrt{ }$ & Carnivore \\
\hline 10 & Fox Kestrel & Falco alopex & Falconidae & $\sqrt{ }$ & $\sqrt{ }$ & Carnivore \\
\hline 11 & Common Kestrel & Falco tinnunculus & Falconidae & $\sqrt{ }$ & $\sqrt{ }$ & Carnivore \\
\hline 12 & Double spur francolin & Francolinus bicalcaratus & Phasianidae & $\sqrt{ }$ & $\sqrt{ }$ & Omnivore \\
\hline 13 & Black billed wood dove & Turtur abyssinicus & Columbidae & $\sqrt{ }$ & $\sqrt{ }$ & Frugivore \\
\hline 14 & African Mourning dove & Streptopelia decepiens & Columbidae & - & $\sqrt{ }$ & Frugivore \\
\hline 15 & Laughing Dove & Streptopelia senegalensis & Columbidae & - & $\sqrt{ }$ & Frugivore \\
\hline 16 & Vinaceous Dove & Streptopelia vinacea & Columbidae & $\sqrt{ }$ & $\sqrt{ }$ & Frugivore \\
\hline 17 & Bruce's Green Pigeon & Treron waalia & Columbidae & $\sqrt{ }$ & $\sqrt{ }$ & Frugivore \\
\hline 18 & Speckled pigeon & Columba guinea & Columbidae & $\sqrt{ }$ & $\sqrt{ }$ & Frugivore \\
\hline 19 & Rose ringed parakeet & Psittacula krameri & Psittacidae & - & $\sqrt{ }$ & Frugivore \\
\hline 20 & Senegal parrot & Poicephalus senegalus & Psittacidae & $\sqrt{ }$ & $\sqrt{ }$ & Frugivore \\
\hline 21 & Abyssinian roller & Coracias abyssinicus & Coraciidae & $\sqrt{ }$ & $\sqrt{ }$ & Insectivore \\
\hline 22 & African Grey hornbill & Tockusnasatus & Bucerotidae & - & $\sqrt{ }$ & Frugivore \\
\hline 23 & Red billed hornbill & Tockus erythrorhynchus & Bucerotidae & - & $\sqrt{ }$ & Frugivore \\
\hline 24 & Bearded barbet & Lybius dubius & Capitonidae & $\sqrt{ }$ & $\sqrt{ }$ & Frugivore \\
\hline 25 & Yellow fronted tinker bird & Pogoniulus chrysoconus & Capitonidae & $\sqrt{ }$ & $\sqrt{ }$ & Frugivore \\
\hline 26 & Cardinal Woodpecker & Dendropicos poecilolaemus & Picidae & $\sqrt{ }$ & $\sqrt{ }$ & Frugivore \\
\hline 27 & Ethiopian Swallow & Hirundo aethiopica & Hirundiniidae & $\sqrt{ }$ & $\sqrt{ }$ & Insectivore \\
\hline 28 & Common Bulbul & Pycnonotus barbatus & Pycnonotidae & $\sqrt{ }$ & $\sqrt{ }$ & Insectivore \\
\hline 29 & African Thrush & Turdeus pelios & Turdidae & $\sqrt{ }$ & $\sqrt{ }$ & Frugivore \\
\hline 30 & Cliff chat & $\begin{array}{l}\text { Myrmeccocichla } \\
\text { cinnamomeiventris }\end{array}$ & Turdidae & - & $\sqrt{ }$ & Frugivore \\
\hline 31 & Northern Ant eater chat & Myrmecocichlaaethiops & Turdidae & $\sqrt{ }$ & $\sqrt{ }$ & Insectivore \\
\hline 32 & White Fronted black chat & Myrmecocichla albifrons & Turdidae & $\sqrt{ }$ & $\sqrt{ }$ & Insectivore \\
\hline 33 & Senegal Eremomela & Eremomela pussila & Cisticolidae & $\sqrt{ }$ & $\sqrt{ }$ & Insectivore \\
\hline 34 & Garden Warbler & Silviaborin & Silviidae & - & $\sqrt{ }$ & Insectivore \\
\hline 35 & Grey backed Camaroptera & Camaroptera brachyuran & Silviidae & - & $\sqrt{ }$ & Insectivore \\
\hline 36 & Tawny Flanked Prinia & Prinia subflava & Silviidae & - & $\sqrt{ }$ & Granivore \\
\hline 37 & White shouldered black tit & Parusleucomelas guineensis & Paridae & - & $\sqrt{ }$ & Granivore \\
\hline 38 & Beautiful sunbird & Cinnyris pulchellus & Nectriniidae & - & $\sqrt{ }$ & Omnivore \\
\hline 39 & Copper Sunbird & Cinnyris cupreus & Nectriniidae & - & $\sqrt{ }$ & Nectarivore \\
\hline 40 & Scarlet Chested sunbird & Chalcomitra senegalensis & Nectriniidae & $\sqrt{ }$ & $\sqrt{ }$ & Nectarivore \\
\hline 41 & Variable Sunbird & Cinnyrisvenustus & Nectriniidae & $\sqrt{ }$ & $\sqrt{ }$ & Nectarivore \\
\hline 42 & Yellow White eye & Zosterops senegalensis & Zosteropidae & $\sqrt{ }$ & $\sqrt{ }$ & Nectarivore \\
\hline 43 & Yellow Bill shrike & Corvinella corvina & Laniidae & $\sqrt{ }$ & $\sqrt{ }$ & Insectivore \\
\hline 44 & Black crown tchagra & Tchagra senegalus & Malaconotidae & $\sqrt{ }$ & $\sqrt{ }$ & Insectivore \\
\hline 45 & Tropical boubou & Laniarus turatii & Malaconotidae & $\sqrt{ }$ & $\sqrt{ }$ & Frugivore \\
\hline
\end{tabular}




\begin{tabular}{|c|c|c|c|c|c|c|}
\hline 46 & Yellow crown Gonolek & Laniarus barbarus & Malaconotidae & $\sqrt{ }$ & $\sqrt{ }$ & Frugivore \\
\hline 47 & Black headed oriole & Oriolus brachyrhynchus & Oriolidae & $\sqrt{ }$ & $\sqrt{ }$ & Frugivore \\
\hline 48 & Pied crow & Corvus albus & Corvidae & - & $\sqrt{ }$ & Frugivore \\
\hline 49 & Long tail glossy starling & Lamprotonis caudatus & Sturnidae & $\sqrt{ }$ & $\sqrt{ }$ & Omnivore \\
\hline 50 & Purple glossy starling & Lamprotornis purpureus & Sturnidae & $\sqrt{ }$ & $\sqrt{ }$ & Granivore \\
\hline 51 & Piapiac & Ptilostomusafer & Sturnidae & - & $\sqrt{ }$ & Granivore \\
\hline 52 & Northern Grey headed & Passer griseus & Passeridae & - & $\sqrt{ }$ & Granivore \\
\hline 53 & Bush Petronia & Petronia dentata & Ploceidae & $\sqrt{ }$ & $\sqrt{ }$ & Granivore \\
\hline 54 & Little Weaver & Ploceus luteolus & Ploceidae & - & $\sqrt{ }$ & Granivore \\
\hline 55 & Village Weaver & Ploceus cucullatus & Ploceidae & $\sqrt{ }$ & - & Granivore \\
\hline 56 & African Silver bill & Eudice cantans & Estrildidae & $\sqrt{ }$ & $\sqrt{ }$ & Granivore \\
\hline 57 & Bronze Mannikin & Spermetes cuccullatus & Estrildidae & $\sqrt{ }$ & $\sqrt{ }$ & Granivore \\
\hline 58 & $\begin{array}{l}\text { Cinnamon Breasted-Rock } \\
\text { Bunting }\end{array}$ & Emberiza tahapisi & Estrildidae & $\sqrt{ }$ & $\sqrt{ }$ & Granivore \\
\hline 59 & Cut throat finch & Amadina fasciata & Estrildidae & $\sqrt{ }$ & $\sqrt{ }$ & Granivore \\
\hline 60 & Red billed Fire Finch & Lagonosticta senegala & Estrildidae & - & $\sqrt{ }$ & Granivore \\
\hline 61 & Orange cheeked waxbill & Estrilda melpoda & Estrildidae & $\sqrt{ }$ & $\sqrt{ }$ & Granivore \\
\hline 62 & Black crown waxbill & Estrilda nonnulacens & Estrildidae & $\sqrt{ }$ & $\sqrt{ }$ & Granivore \\
\hline 63 & Lavender waxbill & Estrilda caerules & Estrildidae & $\sqrt{ }$ & $\sqrt{ }$ & Granivore \\
\hline 64 & Red Cheeked cordon bleu & Uraeginthus bengalus & Estrildidae & $\sqrt{ }$ & $\sqrt{ }$ & Granivore \\
\hline 65 & Western Grey Plantain eater & Crinifer piscator & Musophagidae & $\sqrt{ }$ & $\sqrt{ }$ & Frugivore \\
\hline 66 & Senegal Coucal & Centropus senegalensis & Cuculidae & $\sqrt{ }$ & $\sqrt{ }$ & Frugivore \\
\hline 67 & Grey Headed Kingfisher & Halcyon malimbica & Alcedinidae & $\sqrt{ }$ & $\sqrt{ }$ & Omnivore \\
\hline 68 & Village indigo bird & Vidua chalybeate & Viduidae & $\sqrt{ }$ & - & Granivore \\
\hline 69 & Pintail Whydah & Vidua macoura & Viduidae & $\sqrt{ }$ & - & Granivore \\
\hline
\end{tabular}

\section{DISCUSSION}

Many institutions of higher learning are adorned with ornamental as well as exotic and native tree species. Apart from the primary role of aesthetics, trees are biologically crucial in climate moderation, carbon sequestration, and mitigation of run-offs and floods during the rains. In addition plants help in air purification, shade provision/ wind break and reduction in noise pollution (Novak and Dwyer 2007).It is also a fact that plants inadvertently provide primary habitats for a vast number of life forms thereby promoting biodiversity.

Birds are ubiquitous and have learnt to utilize various habitats both natural and human modified (Borow and Demey, 2004), and as such,we tested whether species assemblage will differ between two distinct habitat types; a human occupiedand a degraded savannah habitat. Our thinking was predicated on the notion that habitat structure is a major predictor of habitat choice by birds as has been suggested by some studies (Nsor, 2006; Abalaka and Manu, 2007; Manu et al., 2007; Manu et al., 2010; Dami et al., 2014).

Our record of 69 avian species is in consonance with similar studies, example Agbo et al. (2018) who recorded 60 avian species in a similar landscape in Kaduna, Kaduna state. Moreover, our findings are in tandem with other surveys within the region of Gombe State where the authors reported species richness values similar to our present findings (Nsor and Adang, 2012; Adang et al, 2015a, Adang et al, 2015b). However, the scale of enquiry (survey duration) may be a limiting factor and a major bias if we were to run a comparative analysis of species richness among the various study sites. Nonetheless, our results indicate, a relatively higher species richness compared to previous studies given that the survey was conducted for just four days. 
Our quest to determine how well avian species make the best of a human modified and degraded savannah habitats was quite revealing; our results suggest that most of the birds in fact $66.7 \%$ use both habitats freely although their distribution may favor one habitat over the other in terms of abundance. For example, the most abundant bird species Laughing Dove Streptopelia senegalensis, Cattle egret Bulbus ibis and Vinaceous dove Streptopelia vinacea were more abundant in the Human inhabited habitat than in the degraded savannah, alluding to the fact that perhaps becoming use to human presence was an adaptive advantage. However, it is interesting to note the possible interplay of resource distribution, competition, and habitat patchiness in driving certain individuals of some species to forage in specific habitats even at the risk of predation. This is in keeping with the source-sink theory and the metapopulation concept (Hanski, 1994, Hanski et al., 1995).

Birds are known to occupy certain feeding guilds, with several species sharing the same food resources. While most studies on resource distribution focused on the spatiotemporal distribution, few have dwelled on the vertical distribution of avian food resources. However in a recent study, Bakam et al (2018) demonstrated how birds utilize resources along a vertical gradient. They authors asserted that the more structurally diverse a habitat is, the more likely it is to support diversity, which is in consonance with the works of Manu (2007). In this study, we recorded 21 frugivorous species occupying various heights in a vertically stratified niche arrangement which keeps them often above their zero elevation foraging counterparts -16 species of granivores, while 18 species of insectivores oscillated between different strata, often spending most of their time on the ground hunting for insects. Omnivorous species on the other hand occupied and fed along a vertical gradient while the birds of prey -6 species of carnivores (raptors) swoop down on their prey from the top stratum where they often perch for hours (Bakam et al., 2018).

This observed partition of resources reduces interspecies competition while facilitating species cooperation. Against this backdrop, it would not be out of place to say that based on the results of this study, that the relatively high level of diversity could be a direct benefit of habitat heterogeneity as reflected in the various feeding guilds highlighted above while also consolidating the notion that vertical stratification of resources is positively associated with avian species diversity and optimizes species richness in concert with other habitat and environmental parameters such as foliage volume and percentage vegetation cover (Karr and Roth, 1971; James and Warner, 1982).
Furthermore, the differences in species composition between the two habitats investigated in this study confirm the notion that a heterogeneous habitat supports more species diversity than a homogeneous one (Abalaka and Manu, 2007; Dami et al., 2014). The human inhabited habitat was found to be dominated by exotic and introduced plant species planted in a ho mogenous pattern (Pringle et al, 2010). This fact coupled with vehicular and human pres ence may be one of the reasons why more species were recorded in the degraded savannah habitat than the human inhabited one (Imong, 2007).

Moreover, most bird species are naturally elusive and avoid habitats that do not offer adequate cover; some of these species e.g. Bush Petronia Petronia dentata, Senegal Parrot Poicephalus senegalus, Tawny flanked Prinia Prinia subflava, Grey Backed Camaroptera Camaroptera brachyuran, Double spur Francolin Poicephaluss enegalus etc.,were found to occur only in the degraded savannah where some remnant shrubby patches offer cover. However because birds are highly mobile apart from the flightless ones, they often go beyond their comfort zones to human inhabited areas especially when the habitats offer some movement "corridors" or safe patches to facilitate movement between distinct habitats (Noss, 1991). This was the case with some species that are seldom seen in isolated human do minated landscape. Some of these human evading and habitat sensitive species (e.g. Yellow crown Gonolek Laniarus barbarous, Black crown Tchagra Tchagra senegalus and the Red-billed Hornbill Lagonosticta senegala were seen freely foraging in the human inhabited habitat in this study.

The aforementioned species could easily forage in both habitats because there was really no clear demarcation between the two habitats. Moreover, some portions of the human inhabited habitats tapered nicely into the degraded savannah contiguously (Noss, 1991). This observation emphasizes the need for landscape experts and environmentalist to design campuses and other public facilities such that natural patches of indigenous flora will be interspersed with buildings and introduced flora. This will go a long way to encourage diurnal movements of avian species between patches and on a broader scale more biodiversity.

\section{CONCLUSION}

The study identified certain anthropogenic activities that may be detrimental to avian species wellbeing and abundance in the study area if urgent actions are not taken. These include but not limited to; indiscriminate and 
unregulated extraction of fuel wood, excessive conversion of remnant woodland to agricultural fields, unsustainable extraction of plants of ethno-botanical importance, unregulated movement of pedestrian and poachers into the college through multiple entry and exit routes.

We urge the college management to as a matter of urgencyblock all unauthorized entry and exit routes to check unsustainable harvest of fuel wood. More native tree species should be reintroduced to mute the invasive effect of exotic species and restore networks of interactions that have been broken with the exit of native key stone tree species. The campus has potential to be a major refuge for birds and other smaller invertebrate species if all stakeholders rejig their commitment to nature and their stewardship obligation to biodiversity.

\section{ACKNOWLEDGEMENT}

We appreciate God Almighty for making it possible. We thank the management of the college for allowing us to work in their college premises.

\section{REFERENCES}

[1] Abalaka, J. I., \& Manu, S. A. (2007). Factors affecting forest bird diversity and recent avifaunal changes in the degrading Kagoro-Nindam forest reserves, Kaduna, Nigeria. Ostrich, 78(2), 233-238.

[2] Adang K.L., Nsor, C.A \&Tela, M. (2015a). Survey of avifauna of Gombe State University, Go mbe, Nigeria. International Journal of Biology and Biological Sciences. 4(2): 032-036.

[3] Adang K.L., Nsor, C.A \&Tela, M. (2015b). Checklist of bird species at Dadin Kowa Dam, Go mbe, Gombe State-Nigeria. Global Advanced Research Journal of Agricultural sciences, 4(5): 276-280

[4] Adang, K.L., Tanko, D., Kachi, J., and Abdulwahab, U. A. (2018). Bird Species richness and Diversity of Lokoja and Environs, Kogi state, Nigeria. Proceedings of the $6^{\text {th }}$ NSCB Biodiversity Conference; UniUyo. Pp.117-124.

[5] Agbo, B. O., Bakam, H., Andong, F. A., Salihu, M. and Abdulhamid, H. (2018) Dawn and Dusk Observation of Bird Abundance and Diversity in the Federal College of Forestry Mechanization Afaka, Kaduna state.Proceedings of the $6^{\text {th }}$ NSCB Biodiversity Conference; UniUyo. Pp.138-143

[6] Borrow, N and Demey, R. (2004). Birds of Western Africa. Christopher Helm Publisher. London.

[7] Bakam, H.;Zubairo, Gideon Philips and Agbo Boniface, O. (2018). Birds of General Hassan Usman
Katsina Park in Relation to Vertical Stratification of Foliage, Kaduna, Nigeria. Proceedings of the $6^{\text {th }}$ NSCB Biodiversity Conference; UniUyo. Pp.408- 415.

[8] Dami, F. D., Mwansat, G. S., \& Shiiwua, A. M. (2014). The Effect of Fragmentation and Land Use Types on Bannerman's Weaver Ploceus bannermani (A Globally-Threatened Bird Species) on the Obudu Plateau, Southeast Nigeria. Journal of Natural Sciences Research, 4(19), 91-97.

[9] Ezealor, A.U. (2002). Critical Sites for Biodiversity Conservation in Nigeria. Nigerian Conservation Foundation, Lagos Nigeria 110p.

[10] Gregory, R. , Noble, D., Field, R., Marchant, J., Raven, M., \& Gibbons, D. W. ( 2003). Using birds as indicators of biodiversity. Ornis Hungarica, 12(13), $11-24$.

[11] Gregory, R. D., Willis, S. G., Jiguet, F., Vorisek, P., KLvanova, A., van Streien, A., . . . Green, R. E. (2009). An indicator of the impact of climatic change on European bird populations. PloS one, 4(3), e4678.

[12] Hanski, I (1994). A practical Model for for Metapopulation Dynamics. The Journal of Animal Ecology, Vol. 63, No. 1. (Jan., 1994), pp. 151-162.

[13] Hanski, I., Pakkala T., Kuussaari M, and Lei, G. (1995). Metapopulation persistence of an endangered butterfly in a fragmented landscape. - Oikos 72: 21-28.

[14] Imong, I. S. (2007). Effects of Habitat Type and Anthropogenic Disturbance on the Density and Distribution of Birds in the Sankwala Mountains, Nigeria, University of Jos. Masters Thesis.

[15] James, F.G., \& Warner, N.O. (1982). Relationships between temperate forest bird communities and vegetation structure. Ecology 63: 159-171.

[16] Jost. L. 2006. Entropy and Diversity. Oikos, 113(2), 363-375

[17] Karr, J.R. \& Roth, R. R. (1971). Vegetation structure and Avian diversity in several New World areas. The American Naturalist 105: 423-435.

[18] Krisanti, A.A., Choirunnafi, A., Septiana, N.O., Pratama, F.W., Amelia, F., Manjaswari, A., Septinigtyas, P.A., Wati, A.S., Satria, J.Y., Ani, I.L. Wibowo, T. and Sugiyarto (2017). The diversity of diurnal bird species on the Western Slope of Mount Lawu, Java, Indonesia. Biodiveritas, 18 (3): 10771083, DOI: 10.13057/biodiv/d180327.

[19] Manu, S., Peach, W., \& Cresswell, W. (2007). The effects of edge, fragment size and degree of isolation on avian species richness in highly fragmented forest in West Africa. Ibis, 149(2), 287-297. 
[20] Manu, S., Imong, I. S., \& Cresswell, W. (2010). Bird species richness and diversity at montane Important Bird Area (IBA) sites in south-eastern Nigeria. Bird Conservation International, 20(3), 231-239.

[21] Noss, R. F. (1991). Landscape connectivity: different functions at different scales. Landscape linkages and biodiversity. Island Press, Washington, DC, USA, 2739.

[22] Nowak, D.J. and Dwyer, J.F. (2007) "Understanding the benefits and costs of urban forest ecosystems," in Urban and CommunityForestry in the Northeast, J. E. Kuser, Ed., pp. 25-46, Springer Dordrecht, The Netherlands, 2nd edition, 2007.

[23] Nsor, C. A. (2006). Habitat Utilization by ten bird species in Amurum forest Reserve, Jos, Plateau StateNigeria. University of Jos Masters Thesis.

[24] Nsor, C. A, Adang, K. L (2012). Guide to birds of Gombe State University, Gombe Nigeria. Pawo graphics and publishers ISBN: 978-978-922-747-1

[25] Odewu mi, O.S., Okosobo, E.F. \&Talabi, O. (2017). Diversity and Abundance of Avian Species of OwenaMultipurpose Dam, Ondo State, South West, Nigeria. Journal of Biodiversity Bioprospecting and Development 4: $163 . \quad$ Doi: $10.4172 / 2376-$ 0214.1000163.

[26] Orme, C.D.L., Davies, R. G., Burgess, M., Eigenbrod, F., Pickup, N., Olson, V. A., . . Ridgely, R. S. (2005). Global hotspots of species richness are not congruent with endemism or threat. Nature, 436(7053), 10161019.

[27] Pauw, A., \& Louw, K. (2012). Urbanization Drives a Reduction in Functional Diversity in a Guild of Nectar-feeding Birds. Ecology and Society, 17(2), 127.

[28] Pearce, J., \& Ferrier, S. (2001). The practical value of modelling relative abundance of species for regional conservation planning: a case study. Biological Conservation, 98(1), 33-43.

[29] Pringle, R. M., Doak, D. F., Brody, A. K., Jocqué, R., \& Palmer, T. M. (2010). Spatial pattern enhances ecosystem functioning in an African savanna. PLoS biology, 8(5), e 1000377

[30] Memmott, J., Waser, N. M., \& Price, M. V. (2004). Tolerance of Pollination Networks to Species Extinctions. Proceedings: Biological Sciences, 271(1557), 2605-2611.

[31] Tilman, D. (1996). Biodiversity: population versus ecosystemstability. Ecology, 77(2), 350-363. 